\title{
Cost-Effectiveness Analysis of Exenatide versus GLP-1 Receptor Agonists in Patients with Type 2 Diabetes Mellitus
}

\author{
Margarita Capel $^{1} \cdot$ Andreea Ciudin $^{2} \cdot$ María Mareque $^{3}\left[\right.$ Raquel María Rodríguez-Rincón $^{4} \cdot$ Susana Simón ${ }^{1}$. \\ Itziar Oyagüez ${ }^{3}$
}

Published online: 23 July 2019

(c) The Author(s) 2019

\begin{abstract}
Objective The aim of this study was to assess the efficiency of exenatide $2 \mathrm{mg} /$ week compared with other glucagon-like peptide-1 (GLP-1) receptor agonists (dulaglutide $1.5 \mathrm{mg} / \mathrm{week}$, liraglutide $1.2 \mathrm{mg} / \mathrm{day}$, liraglutide $1.8 \mathrm{mg} /$ day and lixisenatide $20 \mu \mathrm{g} /$ day) in adult patients with type 2 diabetes mellitus (T2DM) not adequately controlled on metformin alone from the perspective of the Spanish National Health System (NHS).

Methods Quality-adjusted life-years (QALYs) gained and total costs of each assessed drug combined with metformin ( $2 \mathrm{~g} /$ day) were estimated over a 40-year time horizon using the Cardiff Diabetes Model (based on UK Prospective Diabetes Study [UKPDS] 68 equations), which simulates disease progression considering the T2DM-related micro- and macrovascular complications, hypoglycaemia, nausea, body mass index (BMI) changes and treatment discontinuation due to adverse effects (AEs). Drug efficacy derived from an indirect comparison performed in a network meta-analysis. Patient characteristics were obtained from the literature. The baseline utility value $(0.80)$ was derived from the PANORAMA study, applying utility decrements to micro- and macrovascular complications, hypoglycaemia episodes and changes in BMI. Treatment discontinuation due to AEs or poorly controlled diabetes (HbA1c $>7.5 \%$ ) involved switching to second-line (basal insulin) or third-line (basal-bolus insulin) treatment. Total cost $(€, 2018)$ included the costs of drug acquisition, hypoglycaemia, weight gain, micro- and macrovascular complications, nausea and treatment discontinuation due to AEs. An annual discount rate of $3 \%$ was applied to costs and outcomes. Deterministic and probabilistic sensitivity analyses (SA) were performed.

Results In base-case, exenatide $2 \mathrm{mg}$ /week resulted in more QALYs (8.26) than dulaglutide $1.5 \mathrm{mg} /$ week (8.19 QALYs), liraglutide $1.2 \mathrm{mg} /$ day ( 8.10 QALYs), liraglutide $1.8 \mathrm{mg} /$ day ( 8.20 QALYs) and lixisenatide $20 \mu \mathrm{g} / \mathrm{day}$ (8.13 QALYs). Total cost/patient was $€ 20,423.27$ (exenatide $2 \mathrm{mg} /$ week), $€ 22,611.94$ (dulaglutide $1.5 \mathrm{mg} /$ week), $€ 21,065.97$ (liraglutide $1.2 \mathrm{mg} /$ day), $€ 24,865.69$ (liraglutide $1.8 \mathrm{mg} /$ day) and $€ 21,334.58$ (lixisenatide $20 \mu \mathrm{g} /$ day). Deterministic SA confirmed the robustness of the model. In the probabilistic SA, 95-99\% of the 1000 Monte Carlo iterations performed were under a hypothetical willingness-to-pay threshold of $€ 20,000 / \mathrm{QALY}$ gained.

Conclusions Exenatide $2 \mathrm{mg}$ /week would be a dominant strategy (more effective and less costly) versus the other GLP-1 receptor agonists assessed for the treatment of T2DM patients who are not adequately controlled on metformin alone.
\end{abstract}

María Mareque

mmareque@porib.com

AstraZeneca, Madrid, Spain

2 Hospital Universitari Vall d’Hebron, Barcelona, Spain

3 Pharmacoeconomics and Outcomes Research Iberia (PORIB), Paseo Joaquín Rodrigo 4-I, Pozuelo de Alarcón, 28224 Madrid, Spain

4 Hospital Universitari Son Espases, Palma De Mallorca, Spain

\section{Introduction}

Diabetes mellitus (DM) is a chronic disease caused by metabolic abnormalities of multiple aetiologies, and is characterised by chronic hyperglycaemia and abnormalities in carbohydrate, fat, and protein metabolism; it results from defects in insulin secretion, insulin action, or both [1]. The most common type of DM, accounting for up to $90 \%$ of diagnosed cases of the disease, is type $2 \mathrm{DM}$ (T2DM) which is characterised by a relative deficit of insulin secretion and/ or resistance to its action [2]. 


\section{Key Points for Decision Makers}

The results of this cost-effectiveness analysis suggest that exenatide $2 \mathrm{mg} / \mathrm{week}$ is a dominant option compared with other glucagon-like peptide-1 (GLP-1) receptor agonists in patients with type 2 diabetes mellitus inadequately controlled on metformin monotherapy in Spain.

Exenatide $2 \mathrm{mg} /$ week provided more quality-adjusted life-years (QALYs) gained compared with dulaglutide $1.5 \mathrm{mg} /$ week, liraglutide $1.2 \mathrm{mg} /$ day, liraglutide $1.8 \mathrm{mg} /$ day and lixisenatide $20 \mu \mathrm{g} /$ day.

Exenatide $2 \mathrm{mg} /$ week combined with metformin has a lower cost associated with the treatment and management of patients with T2DM versus other GLP-1 receptor agonists.

In Spain, the prevalence of T2DM ranges from 10 to $15 \%$ [3-5], increasing progressively as age increases, and reaching $23.1 \%$ in the $70-74$ years age group [6].

$\mathrm{T} 2 \mathrm{DM}$ is one of the main causes of premature morbidity and mortality in the adult population. The disease, alone or combined with risk factors such as high blood pressure and/ or overweight/obesity, is a significant risk factor for microand macrovascular complications (cardiovascular disease, eye diseases, neuropathies, kidney disease, and amputations) as diabetes progresses [7, 8]. These are some of the main causes of the increased mortality associated with T2DM [9]. Hence, T2DM is one of the most important chronic diseases, with great socioeconomic impact in Spain, not only because of its high prevalence but also because of the acute and chronic complications that occur, which constitute the first cause of years lived with disability (YLD), and because of its high mortality rate [10]. Furthermore, T2DM poses a high economic burden for the National Health System (NHS), with an estimated average cost per patient of $€ 4458$ after 2 years [5].

The main treatment aim in patients with T2DM is to reach and maintain glycaemic control goals, both early on and in the long term, without causing hypoglycaemia, in order to prevent or delay the onset of micro- and macrovascular complications and thus improve the patient's quality of life. Notably, adequate treatment of T2DM requires the simultaneous consideration of overweight/obesity and other cardiovascular risk factors such as hypertension, dyslipidaemia or smoking $[11,12]$.

Personalised treatment is currently the standard therapeutic approach for T2DM. In making decisions, clinicians must consider the particular characteristics of the disease, comorbidity, patient preferences, and available resources $[11,12]$.
The decision for treatment selection among all available therapies depends on the potency to reduce $\mathrm{HbA1c}$, risk of inducing hypoglycaemia, degree of prior control, influence on body weight and dyslipidaemia, preferential impact on basal or postprandial glycaemia, complications or associated diseases of the patient, risk of drug-related adverse effects (AEs), tolerance, and cost. Initial drug treatment varies depending on the degree of prior control, age, presence of associated diseases, and concomitant use of other drugs [11, 12].

In recent years, incorporating glucagon-like peptide-1 (GLP-1) receptor agonists in the initial treatment with metformin has become increasingly important for the treatment of patients with T2DM due to the combined efficacy of the agonists in significantly reducing HbA1c levels [13, 14] without the adverse effects of hypoglycaemia and weight gain that are associated with other oral antidiabetics [15].

The aim of the present study was to evaluate the costeffectiveness of exenatide $2 \mathrm{mg} /$ week compared with other GLP-1 receptor agonists available in Spain (dulaglutide $1.5 \mathrm{mg} /$ week, liraglutide $1.2 \mathrm{mg} / \mathrm{day}$, liraglutide $1.8 \mathrm{mg} /$ day, and lixisenatide $20 \mu \mathrm{g} / \mathrm{day}$ ) for treating patients with T2DM that is not adequately controlled with metformin alone, providing information related to outcomes and costs which could help decision makers for reallocating available resources.

\section{Materials and methods}

Cost-effectiveness analysis was used to evaluate the efficacy of exenatide combined with metformin versus other GLP-1 receptor agonists available for the management of patients with T2DM in Spain. To perform the analysis in the Spanish environment, a discrete-event stochastic simulation model (Cardiff Diabetes Model) that had been previously validated [16] was used to simulate the progression of patients with T2DM.

The model simulated the natural history of T2DM in a cohort of 1000 patients, while considering treatment efficacy, T2DM-related micro- and macrovascular complications, drug AEs, and associated costs, and was adapted to usual clinical practice in Spain. The risk of microvascular (amputation, blindness, and end-stage renal disease) and macrovascular (ischaemic heart disease, myocardial infarction, stroke, and congestive heart failure) complications was estimated based on UK Prospective Diabetes Study (UKPDS) 68 risk equations [17].

The simulation was performed individually for each patient in the cohort in 6-month cycles until the end of the time horizon considered or the patient's death. The analysis was performed for each treatment option and was subsequently compared to estimate the incremental cost-effectiveness ratio (ICER). 
Anthropometric, demographic, and baseline clinical characteristics defining the cohort of patients evaluated were obtained from the literature and represented the profile of patients with T2DM in Spain (Table 1). Demographic characteristics included mean age, proportion of women, mean height, mean duration of T2DM, proportion of smokers and mean patient weight. In the model, the variables that were considered modifiable risk factors to reflect any treatment effect included $\mathrm{HbA1c}$, total cholesterol and HDL cholesterol levels, and systolic blood pressure (SBP).

In this analysis, a long-term time horizon that contemplated the whole life of the patient was considered. It established the maximum simulation duration of 40 years per patient since entering the model. In this way, qualityadjusted life-years (QALYs) gained were estimated, along with the total cost attributable to each treatment alternative from the perspective of the NHS in Spain. An annual discount rate of $3 \%$ was applied to both costs and health effects, according to the available recommendations for the development of a cost-effectiveness analysis in Spain [18].
Development of the model required the advice of a panel of experts composed of an endocrinologist and a hospital pharmacist specialising in the treatment of T2DM, to validate and reach a consensus on the values identified in the literature for the parameters included in the model, through a structured questionnaire. All values used in the base-case were agreed upon during a meeting with the experts.

\subsection{Treatment Alternatives Evaluated}

The initial cohort included patients with T2DM who had not achieved adequate glycaemic control with the maximum tolerated dose of oral metformin alone and had started treatment with a GLP-1 receptor agonist combined with metformin. The GLP-1 receptor agonists considered in the model were exenatide $2 \mathrm{mg} /$ week, dulaglutide $1.5 \mathrm{mg} /$ week, liraglutide $1.2 \mathrm{mg} /$ day, liraglutide $1.8 \mathrm{mg} /$ day, and lixisenatide $20 \mu \mathrm{g} / \mathrm{day}$; all treatments were combined with metformin (2000 mg/day). Each patient received a firstline treatment of GLP-1 receptor agonists combined with metformin as long as HbA1c levels remained below 7.5\%

Table 1 Parameters used in the model

\begin{tabular}{|c|c|c|c|c|c|c|}
\hline & \multicolumn{2}{|l|}{ Parameter } & \multicolumn{2}{|l|}{ Value } & \multicolumn{2}{|c|}{ Distribution for PSA } \\
\hline & \multicolumn{2}{|l|}{ Mean age (years) [22] } & \multicolumn{2}{|l|}{67.7} & \multicolumn{2}{|l|}{ Normal } \\
\hline \multirow[t]{4}{*}{ Demographic characteristics } & \multicolumn{2}{|l|}{ Proportion female (\%) [22] } & \multicolumn{2}{|l|}{47.10} & & \\
\hline & \multicolumn{2}{|c|}{ Mean duration of T2DM (years) [38] } & \multicolumn{2}{|l|}{10.07} & & \\
\hline & \multicolumn{2}{|c|}{ Mean height (m) [51] /weight (kg) [52] } & \multicolumn{2}{|l|}{$1.67 / 73.50$} & & \\
\hline & \multicolumn{2}{|l|}{ Proportion smokers (\%) [38] } & \multicolumn{2}{|l|}{12.10} & & \\
\hline \multirow[t]{3}{*}{ Clinical features } & \multicolumn{2}{|l|}{ Baseline HbA1c level (\%) [38] } & \multicolumn{2}{|l|}{7.28} & \multicolumn{2}{|l|}{ Normal } \\
\hline & \multicolumn{2}{|c|}{ Total cholesterol [53] /HDL (mg/dl) [5] } & \multicolumn{2}{|l|}{$200.60 / 42.30$} & & \\
\hline & \multicolumn{2}{|l|}{$\mathrm{SBP}(\mathrm{mmHg})[54]$} & \multicolumn{2}{|l|}{125.4} & & \\
\hline \multirow[t]{12}{*}{ Utility and utility decrements } & \multicolumn{2}{|l|}{ Baseline utility (SE) [22] } & \multicolumn{2}{|l|}{$0.8(0.20)$} & \multicolumn{2}{|l|}{ Beta } \\
\hline & \multicolumn{2}{|l|}{ Ischaemic heart disease (SE) [23] } & \multicolumn{2}{|l|}{$-0.09(0.02)$} & & \\
\hline & \multicolumn{2}{|l|}{ Myocardial infarction (SE) [23] } & \multicolumn{2}{|l|}{$-0.055(0.01)$} & & \\
\hline & \multicolumn{2}{|l|}{ Congestive heart failure (SE) [23] } & $-0.108(0.03$ & & & \\
\hline & Stroke(SE) [23] & & $-0.164(0.03$ & & & \\
\hline & Amputation (SE) [23] & & $-0.28(0.06)$ & & & \\
\hline & Blindness (SE)[23] & & $-0.074(0.03$ & & & \\
\hline & End-stage renal disease (SE) [24] & & $-0.175(0.03$ & & & \\
\hline & Severe hypoglycaemic episode ( $\mathrm{S}$ & & $-0.047(0.01)$ & & & \\
\hline & Symptomatic hypoglycaemic epis & [25] & $-0.0142(0.0$ & & & \\
\hline & $\mathrm{BMI}$-increase of one unit (SE) [ & & $-0.0472(0.0$ & & & \\
\hline & $\mathrm{BMI}$-decrease of one unit (SE) & & $+0.0171(0.00$ & & & \\
\hline Efficacy [20] & & EQW 2 & DULA 1.5 & LIRA 1.2 & LIRA 1.8 & LIXI 20 \\
\hline & $\Delta \mathrm{HbA} 1 \mathrm{c}(\%)[\mathrm{SE}]$ & $-1.34[0.31]$ & $-1.34[0.27]$ & $-0.96[0.20]$ & $-1.28[0.66]$ & $-0.75[0.15]$ \\
\hline & $\Delta$ Weight $(\mathrm{kg})[\mathrm{SE}]$ & $-2.04[1.22]$ & $-2.38[0.49]$ & $-2.72[0.56]$ & $-3.09[0.63]$ & $-1.84[0.38]$ \\
\hline & Discontinuation due to AEs [SE] & $0.063[0.01]$ & $0.14[0.03]$ & $0.12[0.02]$ & $0.13[0.03]$ & $0.03[0.01]$ \\
\hline & Nausea as AEs [SE] & $0.24[0.05]$ & $0.52[0.11]$ & $0.44[0.09]$ & $0.49[0.10]$ & $0.31[0.06]$ \\
\hline & Symptomatic hypoglycaemia & NA & NA & NA & NA & NA \\
\hline & Severe hypoglycaemia & NA & NA & NA & NA & NA \\
\hline
\end{tabular}

T2DM type 2 diabetes mellitus, AEs adverse effects, BMI body mass index, DULA 1.5 dulaglutide 1.5 mg/week, EQW2 exenatide 2 mg/week, HbA1c glycosylated haemoglobin, HDL high-density lipoprotein cholesterol, LIRA 1.2 liraglutide $1.2 \mathrm{mg} /$ day, LIRA 1.8 liraglutide $1.8 \mathrm{mg} /$ day, LIXI 20 lixisenatide $20 \mu \mathrm{g} / \mathrm{day}$, NA not available, PSA probabilistic sensitivity analyses, SBP systolic blood pressure, SE standard error 
$[12,19]$; when HbA1c levels exceeded $7.5 \%$ or treatment was discontinued, patients switched to a second-line treatment with basal insulin (40 IU/day). Patients receiving basal insulin who had exceeded the established $\mathrm{HbA} 1 \mathrm{c}$ threshold switched to a third-line treatment with an intensive insulin regimen (basal insulin [40 IU/day] + bolus insulin [20 IU/ day]) and remained on this treatment until the end of the established time horizon or their death. HbAlc levels were checked annually and the treatment was administered to patients with HbA1c levels exceeding the threshold.

The likelihood of clinical events considered in the model was determined by the efficacy of each treatment, which was represented by the reduction of $\mathrm{HbA} 1 \mathrm{c}$ levels, changes in body weight, treatment-related AEs (hypoglycaemia and nausea), and the probability of treatment discontinuation (Table 1). Efficacy values for each treatment considered in the analysis were derived from an indirect comparison performed in a meta-analysis [20] in which the relative clinical efficacy of exenatide, as well as its tolerability, were compared with other GLP-1 receptor agonists in treating adult patients with T2DM who were inadequately controlled with metformin. For neutral protamine hagedorn (NPH) insulin, the values proposed in the guideline of the National Institute of Health and Care Excellence (NICE) on the management of adult patients with T2DM were used [19]. The model considered treatment effects during the first year and assumed patients progressed later according to the equations resulting from the UKPDS 68 study [17].

\subsection{Mortality}

All-cause mortality data were applied to show the annual probability of death by age and sex, derived from the Spanish mortality tables [21]. In addition, T2DM patients present with a higher risk of dying from other causes than the general population, therefore mortality related to T2DM and its associated complications were considered in the analysis. These data were estimated from the UKPDS 68 equations [17].

\subsection{Utilities}

Utilities as a reflection of the quality of life of patients in different health states were used to adjust survival and to estimate QALYs. The study considered a baseline utility of 0.80 , which was estimated from the results obtained using the EuroQol 5D questionnaire (EQ-5D) in a sample of Spanish patients with T2DM aged over 40 years [22]. Furthermore, baseline utility decrements associated with micro- and macrovascular complications [23, 24], hypoglycaemic episodes [25], and change in body mass index (BMI) [26] were applied. Table 1 describes the utilities and utility decrements used in the present study.

\subsection{Costs}

According to the perspective used, only direct healthcare costs were considered in the analysis (drug acquisition costs, costs of T2DM-related complications, costs associated with BMI increase due to weight gain, and hypoglycaemia, treatment discontinuation, and AE costs). The costs identified in the literature were updated to 2018 values based on the Spanish general consumer price index [27], and all costs were expressed in 2018 Euros (Table 2).

\subsubsection{Cost of Drug Acquisition}

Drug acquisition costs were calculated from the recommended retail price (RRP) + value added tax (VAT) published in the BOT Plus Catalogue of Medicines of the General Council of Official Associations of Pharmacists in Spain [28], applying the deduction corresponding to Royal DecreeLaw 8/2010 [29]. The annual exenatide acquisition cost was estimated from the reference price listed in the reference price order [30]. The study considered the lowest price of available preparations (Bydureon $2 \mathrm{mg}$ powder and solvent for prolonged-release suspension for injection in a pre-filled pen, four single-dose pens) (Table 2).

Annual treatment costs considered in the model were determined, along with the recommended dose for each treatment [31]: metformin $2000 \mathrm{mg} /$ day ( $€ 33.35$ ), exenatide $2 \mathrm{mg} /$ week (€1217.59), dulaglutide $1.5 \mathrm{mg} /$ week (€1821.42), liraglutide $1.2 \mathrm{mg} /$ day (€1555.97), liraglutide $1.8 \mathrm{mg} /$ day (€2333.95), lixisenatide $20 \mu \mathrm{g} /$ day (€1503.13), basal insulin (glargine) $40 \mathrm{IU} /$ day (€168.51), and bolus insulin (aspart) 20 IU/day (€673.99).

\subsubsection{Cost of Type 2 Diabetes Mellitus-Related Complications}

The management costs of T2DM-related micro- and macrovascular complications (in which fatal and non-fatal events were distinguished) were obtained from various sources [32-35], updated to 2018 Euros, and applied only during the year the complication occurred. For surviving patients, the annual maintenance costs associated with each complication were considered until the end of the time horizon of the simulation or the patient's death (Table 2).

\subsubsection{Costs Associated with the Increase in Weight/Body Mass Index}

The annual costs associated with the increase in BMI was estimated by sex, based on a study from the UK [36] reporting a direct relationship between the cost of prescription drugs and the increase in a patient's BMI. 
Table 2 Unitary cost $(€, 2018)$

\begin{tabular}{|c|c|c|c|c|}
\hline \multirow[t]{3}{*}{ Parameter } & \multicolumn{3}{|c|}{ Unit cost $(€, 2018)$} & \multirow{3}{*}{$\begin{array}{l}\text { Distribution for } \\
\text { PSA }\end{array}$} \\
\hline & \multicolumn{2}{|l|}{ First-year cost } & \multirow[t]{2}{*}{ Maintenance cost $(€)$} & \\
\hline & Fatal event $(€)$ & Non-fatal event $(€)$ & & \\
\hline \multicolumn{5}{|l|}{ T2DM complications } \\
\hline Ischaemic heart disease (SE) [32] & - & $2335(476.63)$ & $887(181.06)$ & Gamma \\
\hline Myocardial infarction (SE) [32] & $4755(970.61)$ & $5132(1047.57)$ & $887(181.06)$ & Gamma \\
\hline Stroke (SE) [33] & $4755(970.61)$ & $6532(1333.34)$ & $2551(520.72)$ & Gamma \\
\hline Congestive heart failure (SE) [32] & $4755(970.61)$ & $3451(704.43)$ & $3662(747.50)$ & Gamma \\
\hline Amputation (SE) [32] & $3782(772)$ & $11,605(2368.86)$ & $1702(347.42)$ & Gamma \\
\hline Blindness (SE) [34] & - & $1932(394.37)$ & $829(169.22)$ & Gamma \\
\hline \multirow[t]{2}{*}{ End-stage renal disease (SE) [35] } & - & $31,451(6419.91)$ & $31,451(6419.91)$ & Gamma \\
\hline & & & Cost $(€)$ & \\
\hline \multicolumn{5}{|l|}{ Hypoglycaemic episode } \\
\hline Severe hypoglycaemia (SE) [37] & & & $1154(235.56)$ & Gamma \\
\hline \multicolumn{5}{|l|}{ Adverse effects } \\
\hline Nausea (SE) [35] & & & $59.77(12.20)$ & Gamma \\
\hline Treatment discontinuation (SE) [35] & & & $59.77(12.20)$ & Gamma \\
\hline Drug treatment $[28]$ & Dose & RRP per pack $(€)$ & $\mathrm{RRP}+\mathrm{VAT}(€)$ & Annual cost $(€)$ \\
\hline Metformin & 2000 mg/day & 1.94 & 1.94 & 33.35 \\
\hline Exenatide $^{\mathrm{a}}$ & $2 \mathrm{mg} /$ week & 89.75 & 93.34 & 1217.59 \\
\hline Dulaglutide & $1.5 \mathrm{mg} /$ week & 145.14 & 150.95 & 1821.42 \\
\hline \multirow[t]{2}{*}{ Liraglutide } & $1.2 \mathrm{mg} /$ day & 132.84 & 138.16 & 1555.97 \\
\hline & $1.8 \mathrm{mg} /$ day & 132.84 & 138.16 & 2333.95 \\
\hline Lixisenatide & $20 \mu \mathrm{g} /$ day & 119.78 & 124.57 & 1503.13 \\
\hline Basal insulin (glargine) & 40 IU/day & 55.49 & 57.71 & 168.51 \\
\hline Bolus insulin (aspart) & $20 \mathrm{IU} /$ day & 45.17 & 46.97 & 673.99 \\
\hline
\end{tabular}

$T 2 D M$ type 2 diabetes mellitus, $R R P$ recommended retail price, $P S A$ probabilistic sensitivity analyses, SE standard error, VAT value added tax

${ }^{a}$ Reference RRP is considered

\subsubsection{Cost of Hypoglycaemia and Adverse Effects}

In relation to hypoglycaemic episodes, only the cost of severe hypoglycaemia was considered [37], assuming that symptomatic hypoglycaemic episodes do not involve health resource consumption. The cost of AEs included the costs associated with nausea and treatment discontinuation, assuming the cost equivalent for a primary care physician visit for the management of each issue. The cost of the visit was derived from a health costs database at the national level [35] (Table 2).

\subsection{Sensitivity Analysis}

To evaluate the influence of parameter variation on the model results and to confirm model robustness, univariate and probabilistic sensitivity analyses (SA) were performed.

In univariate SA, different parameters were modified individually, including the time horizon of the study (20 years), discount rate ( $0 \%$ and $5 \%)$, utility value $(0.684$ derived from the CODE-2 study [38]), utility decrement value associated with the change in BMI $( \pm 0.0061)$ [22], HbA1c threshold of $8.5 \%$ for switching to the next line of treatment [39], and bolus insulin dose (40 IU/day). Additionally, the impact of a weight increase $(2.82 \mathrm{~kg})$ [40] in patients reaching the third line of intensive insulin treatment was explored.

In order to explore the uncertainty of assumptions carried out to the mean baseline $\mathrm{HbA1c}$ value, a univariate SA was performed using the mean baseline HbA1c (8.2\%) applied in the network meta-analysis in relation to the HbA1c reductions of the treatment effects [20]. Furthermore, to express the lower baseline $\mathrm{HbA} 1 \mathrm{c}$ value used in the present model (7.28\%), the efficacy estimates for the different drugs observed in the network meta-analysis were down-adjusted by a factor of $7.28 \% / 8.2 \%$.

The probabilistic SA consisted of the simultaneous change of all potentially relevant parameters by a Monte Carlo simulation (1000 iterations) by applying different 
probability distributions to the considered parameters. Applied functions had a normal distribution for baseline characteristics, gamma distribution for cost parameters, and beta distribution for utility data (Fig. 1).

\section{Results}

\subsection{Base-Case}

Exenatide $2 \mathrm{mg} /$ week was associated with 8.26 QALYs and was the most effective option compared with dulaglutide $1.5 \mathrm{mg} /$ week (8.19 QALYs), liraglutide $1.2 \mathrm{mg} /$ day $(8.10$ QALYs), liraglutide $1.8 \mathrm{mg} /$ day (8.20 QALYs), and lixisenatide $20 \mu \mathrm{g} /$ day ( 8.13 QALYs).

The total cost per patient at the end of the simulation was $€ 20,423.27$ with exenatide $2 \mathrm{mg} /$ week, $€ 22,611.94$ with dulaglutide $1.5 \mathrm{mg} /$ week, $€ 21,065.97$ with liraglutide $1.2 \mathrm{mg} /$ day, $€ 24,865.69$ with liraglutide $1.8 \mathrm{mg} /$ day, and $€ 21,334.58$ with lixisenatide $20 \mu \mathrm{g} / \mathrm{day}$.

Based on these results, exenatide $2 \mathrm{mg} /$ week combined with metformin for the treatment of patients with T2DM was a dominant alternative, i.e. it is more effective and less costly than dulaglutide $1.5 \mathrm{mg} /$ week, liraglutide $1.2 \mathrm{mg} / \mathrm{day}$, liraglutide $1.8 \mathrm{mg} /$ day, and lixisenatide $20 \mu \mathrm{g} /$ day (Table 3 ).

\subsection{Sensitivity Analysis}

Univariate SA confirmed the robustness of the results in the 10 proposed scenarios. Exenatide $2 \mathrm{mg} /$ week was a dominant strategy over dulaglutide $1.5 \mathrm{mg} /$ week, liraglutide $1.2 \mathrm{mg} / \mathrm{day}$, liraglutide $1.8 \mathrm{mg} /$ day, and lixisenatide $20 \mu \mathrm{g} /$ day in all deterministic SA performed (Table 4).

The probabilistic SA revealed that exenatide $2 \mathrm{mg} /$ week was more cost effective than the other GLP-1 receptor agonists evaluated, with a probability of between 95 and $99 \%$; this analysis assumed the latest willingness-to-pay threshold of $€ 20,000$ per QALY gained proposed for Spain (Fig. 1) [41].

\section{Discussion}

The present study shows exenatide $2 \mathrm{mg} /$ week is an economically dominant strategy compared with dulaglutide $1.5 \mathrm{mg} /$ week, liraglutide $1.2 \mathrm{mg} / \mathrm{day}$, liraglutide $1.8 \mathrm{mg} / \mathrm{day}$, and lixisenatide $20 \mu \mathrm{g} /$ day. The results obtained in the univariate SA did not vary significantly with respect to the base case.

T2DM has a significant impact due to its economic burden [42]. In this sense, the present analysis suggests that treatment with exenatide $2 \mathrm{mg} /$ week combined with
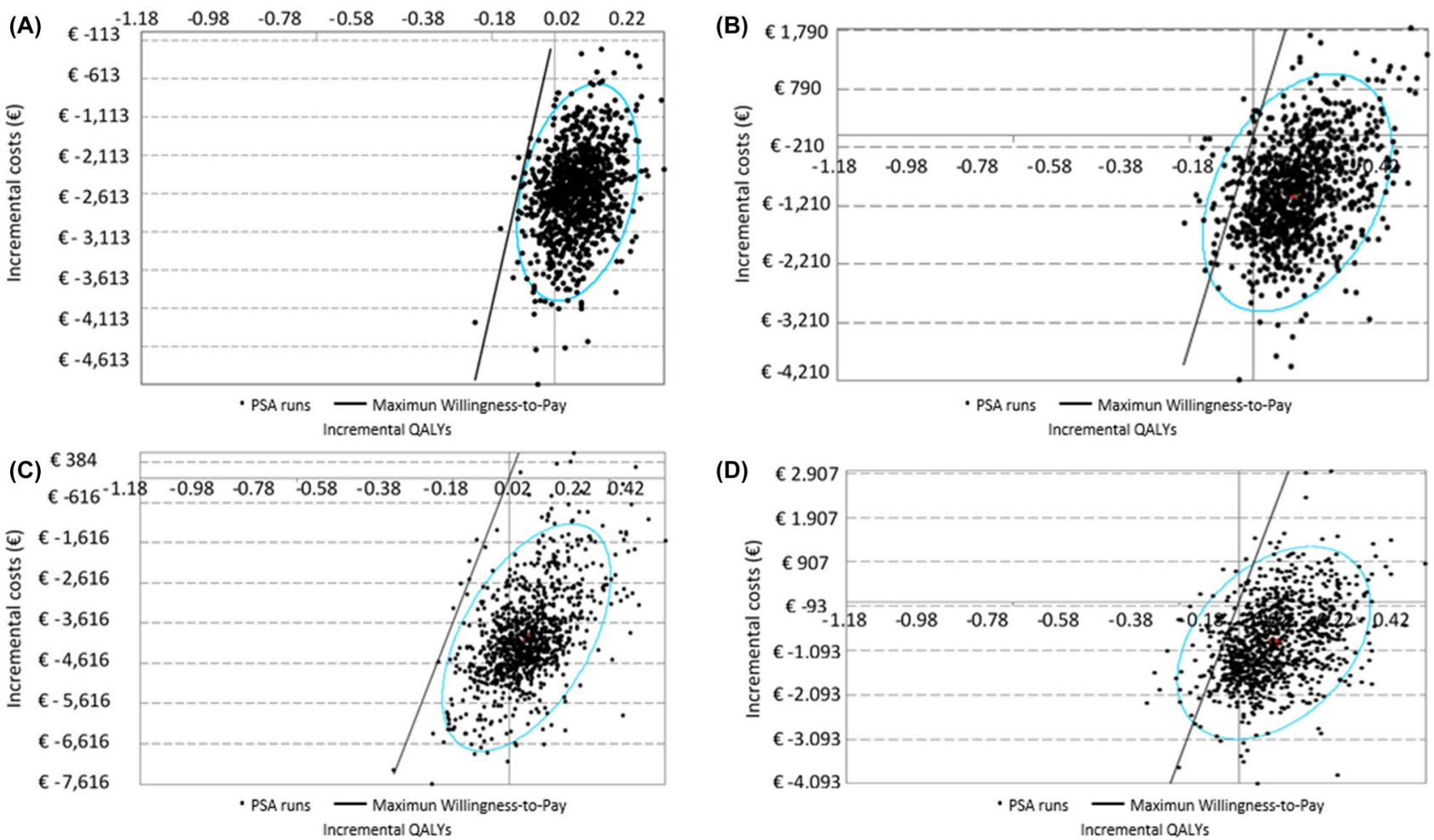

A) Exenatide $2 \mathrm{mg} /$ week vs Dulaglutide $1.5 \mathrm{mg} /$ week; B) Exenatide $2 \mathrm{mg} /$ week vs Liraglutide $1.2 \mathrm{mg} /$ day; C) Exenatide $2 \mathrm{mg} /$ week vs Liraglutide $1.8 \mathrm{mg} / \mathrm{day}$; D) Exenatide 2 $\mathrm{mg} /$ week vs Lixisenatide $20 \mu \mathrm{g} / \mathrm{day}$

Fig. 1 Probabilistic sensitivity analyses 
Table 3 Base-case results

\begin{tabular}{|c|c|c|c|c|c|}
\hline & Exenatide $2 \mathrm{mg}$ & Dulaglutide $1.5 \mathrm{mg}$ & Liraglutide $1.2 \mathrm{mg}$ & Liraglutide $1.8 \mathrm{mg}$ & Lixisenatide $20 \mu \mathrm{g}$ \\
\hline QALY & 8.26 & 8.19 & 8.10 & 8.20 & 8.13 \\
\hline Total costs $(€)$ & $20,423.27$ & $22,611.94$ & $21,065.97$ & $24,865.69$ & $21,334.58$ \\
\hline Drug acquisition cost $(€)$ & $10,840.29$ & $12,988.86$ & $11,406.55$ & $15,228.39$ & $11,691.97$ \\
\hline Cost of T2DM complications $(€)$ & 8026.08 & 8057.27 & 8097.98 & 8073.31 & 8089.01 \\
\hline Cost of changes in BMI $(€)$ & 1546.39 & 1544.04 & 1542.66 & 1543.43 & 1542.83 \\
\hline Cost of hypoglycaemia & - & - & - & - & - \\
\hline Cost of adverse effects $(€)$ & 10.51 & 21.77 & 18.78 & 20.56 & 10.77 \\
\hline & \multicolumn{2}{|c|}{$\Delta \mathrm{QALY}$} & \multicolumn{2}{|c|}{$\Delta$ Costs $(€)$} & ICER \\
\hline \multicolumn{6}{|l|}{ Exenatide $2 \mathrm{mg}$ vs. } \\
\hline Dulaglutide $1.5 \mathrm{mg}$ & \multicolumn{2}{|c|}{0.07} & \multicolumn{2}{|l|}{-2189} & Dominant \\
\hline Liraglutide $1.2 \mathrm{mg}$ & \multicolumn{2}{|c|}{0.15} & \multicolumn{2}{|l|}{-643} & Dominant \\
\hline Liraglutide $1.8 \mathrm{mg}$ & \multicolumn{2}{|c|}{0.06} & \multicolumn{2}{|l|}{-4442} & Dominant \\
\hline Lixisenatide $20 \mu \mathrm{g}$ & \multicolumn{2}{|c|}{0.12} & \multicolumn{2}{|l|}{-911} & Dominant \\
\hline
\end{tabular}

$Q A L Y$ quality-adjusted life-year, T2DM type 2 diabetes mellitus, $B M I$ body mass index, ICER incremental cost-effectiveness ratio

metformin could be a dominant treatment option versus other GLP-1 receptor agonists by reducing costs associated with the treatment and management of patients with T2DM.

The available evidence shows that the effectiveness and tolerability of exenatide is comparable to those of other GLP-1 receptor agonists. Based on these conclusions, the clinical prescription of a GLP-1 receptor agonist should consider treatment personalisation, cost, and efficiency [43].

To our knowledge, this is the first study of a cost-effectiveness analysis in Spain comparing exenatide with dulaglutide, liraglutide, and lixisenatide in patients with T2DM that is inadequately controlled with metformin alone. Therefore, in the Spanish context, it is not possible to compare the results with other studies. Nevertheless, our results are similar to those published in an economic analysis performed in the UK [44].

In a review of the literature, four economic analyses were identified comparing one GLP-1 receptor agonist with another. These studies were conducted in France [45], Italy [46], the UK [47], and Spain [48]. The diversity of methods and treatment alternatives used in these analyses prevented comparing the conclusions with those of the present study.

As a limitation and possible analysis bias, one could comment on the methodology used to consider efficacy variables. Due to the absence of direct-comparison clinical trials among the alternatives evaluated, efficacy data from an indirect comparison performed in a meta-analysis were used [20]. Although indirect comparisons are a standard method that can provide useful and complementary data about the relative efficacy of compared interventions [49], they are subject to greater bias than direct comparisons and may overestimate the effectiveness of interventions. One underlying assumption is the application of $\mathrm{HbA} 1 \mathrm{c}$ reduction estimates from the meta-analysis, which were derived from studies with mean baseline HbA1c levels of $8.2 \%$, to the Spanish hypothetical cohort with a baseline HbA1c set at $7.28 \%$ in the case base. However, the efficacy estimates for the different drugs are all derived in the same way, therefore incremental differences in outcomes are not expected to affect the estimated pairwise ICERs. The influence of this parameter was tested in a SA, where it was found that there were no differences in the results obtained in the base case.

Another possible limitation is related to the use of data extracted from the literature of studies conducted in other countries, as no studies have been conducted specifically in Spain. Utility decrements associated with micro- and macrovascular complications [17], and those related to hypoglycaemia [25], used in the model were derived from two studies in the UK, while utility decrements associated with weight gain were derived from a Canadian study [26]. In the same way, data obtained from a study in the UK [36] were used to estimate costs associated with weight gain in patients with T2DM. All these data were validated by the panel of experts who considered the data representative of the Spanish population with T2DM.

In this sense, there is published evidence suggesting that utility decrement values for different health states in six European countries (Finland, Germany, The Netherlands, Spain, Sweden and the UK) could be described by a common model; therefore, no relevant influence is expected to be associated with the use of disutility values from the UK population, instead of specific values for Spanish patients [50]. 
Table 4 Deterministic sensitivity analysis results

\begin{tabular}{|c|c|c|c|c|c|}
\hline \multicolumn{3}{|l|}{ Sensitivity analysis } & \multirow{2}{*}{$\frac{\Delta \mathrm{QALY}}{0.07}$} & \multirow{2}{*}{$\frac{\Delta \text { Costs }(€)}{-2224}$} & \multirow{2}{*}{$\frac{\text { ICER }}{\text { Dominant }}$} \\
\hline 20-year time horizon & Exenatide $2 \mathrm{mg}$ vs. & Dulaglutide $1.5 \mathrm{mg}$ & & & \\
\hline & & Liraglutide $1.2 \mathrm{mg}$ & 0.16 & -654 & Dominant \\
\hline & & Liraglutide $1.8 \mathrm{mg}$ & 0.06 & -4433 & Dominant \\
\hline & & Lixisenatide $20 \mu \mathrm{g}$ & 0.12 & -923 & Dominant \\
\hline \multirow[t]{4}{*}{ Discount rate $0 \%$} & \multirow[t]{4}{*}{ Exenatide 2 mg vs. } & Dulaglutide $1.5 \mathrm{mg}$ & 0.08 & -2314 & Dominant \\
\hline & & Liraglutide $1.2 \mathrm{mg}$ & 0.18 & -637 & Dominant \\
\hline & & Liraglutide $1.8 \mathrm{mg}$ & 0.07 & -4701 & Dominant \\
\hline & & Lixisenatide $20 \mu \mathrm{g}$ & 0.15 & -936 & Dominant \\
\hline \multirow[t]{4}{*}{ Discount rate $5 \%$} & \multirow[t]{4}{*}{ Exenatide $2 \mathrm{mg}$ vs. } & Dulaglutide $1.5 \mathrm{mg}$ & 0.06 & -2111 & Dominant \\
\hline & & Liraglutide $1.2 \mathrm{mg}$ & 0.14 & -645 & Dominant \\
\hline & & Liraglutide $1.8 \mathrm{mg}$ & 0.05 & -4284 & Dominant \\
\hline & & Lixisenatide $20 \mu \mathrm{g}$ & 0.11 & -897 & Dominant \\
\hline \multirow[t]{4}{*}{ Utility value 0.684} & \multirow[t]{4}{*}{ Exenatide $2 \mathrm{mg}$ vs. } & Dulaglutide $1.5 \mathrm{mg}$ & 0.06 & -2189 & Dominant \\
\hline & & Liraglutide $1.2 \mathrm{mg}$ & 0.15 & -643 & Dominant \\
\hline & & Liraglutide $1.8 \mathrm{mg}$ & 0.05 & -4442 & Dominant \\
\hline & & Lixisenatide $20 \mu \mathrm{g}$ & 0.12 & -911 & Dominant \\
\hline \multirow{4}{*}{$\begin{array}{l}\text { Weight gain utility decrement } \\
\text { Increase in BMI: }-0.0061 \\
\text { Decrease in BMI: }+0.0061\end{array}$} & \multirow[t]{4}{*}{ Exenatide $2 \mathrm{mg}$ vs. } & Dulaglutide $1.5 \mathrm{mg}$ & 0.05 & -2189 & Dominant \\
\hline & & Liraglutide $1.2 \mathrm{mg}$ & 0.12 & -643 & Dominant \\
\hline & & Liraglutide $1.8 \mathrm{mg}$ & 0.05 & -4442 & Dominant \\
\hline & & Lixisenatide $20 \mu \mathrm{g}$ & 0.09 & -911 & Dominant \\
\hline \multirow[t]{4}{*}{ HbA1c threshold $8.5 \%$} & \multirow[t]{4}{*}{ Exenatide $2 \mathrm{mg}$ vs. } & Dulaglutide $1.5 \mathrm{mg}$ & 0.11 & -3802 & Dominant \\
\hline & & Liraglutide $1.2 \mathrm{mg}$ & 0.11 & -2504 & Dominant \\
\hline & & Liraglutide $1.8 \mathrm{mg}$ & 0.09 & -7700 & Dominant \\
\hline & & Lixisenatide $20 \mu \mathrm{g}$ & 0.01 & -2701 & Dominant \\
\hline \multirow{4}{*}{$\begin{array}{l}\text { Weight change (third-line treatment) } \\
2.82 \mathrm{~kg}\end{array}$} & \multirow[t]{4}{*}{ Exenatide $2 \mathrm{mg}$ vs. } & Dulaglutide $1.5 \mathrm{mg}$ & 0.07 & -2180 & Dominant \\
\hline & & Liraglutide $1.2 \mathrm{mg}$ & 0.15 & -640 & Dominant \\
\hline & & Liraglutide $1.8 \mathrm{mg}$ & 0.06 & -4435 & Dominant \\
\hline & & Lixisenatide $20 \mu \mathrm{g}$ & 0.12 & -896 & Dominant \\
\hline \multirow{4}{*}{ Bolus insulin dose 40 IU/day } & \multirow[t]{4}{*}{ Exenatide $2 \mathrm{mg}$ vs. } & Dulaglutide $1.5 \mathrm{mg}$ & 0.07 & -2254 & Dominant \\
\hline & & Liraglutide $1.2 \mathrm{mg}$ & 0.15 & -665 & Dominant \\
\hline & & Liraglutide $1.8 \mathrm{mg}$ & 0.06 & -4498 & Dominant \\
\hline & & Lixisenatide $20 \mu \mathrm{g}$ & 0.12 & -1031 & Dominant \\
\hline \multirow[t]{4}{*}{ Mean baseline $\mathrm{HbA} 1 \mathrm{c}$ value $8.2 \%$} & \multirow[t]{4}{*}{ Exenatide $2 \mathrm{mg}$ vs. } & Dulaglutide $1.5 \mathrm{mg}$ & 0.05 & -1381 & Dominant \\
\hline & & Liraglutide $1.2 \mathrm{mg}$ & 0.17 & -193 & Dominant \\
\hline & & Liraglutide $1.8 \mathrm{mg}$ & 0.03 & -2834 & Dominant \\
\hline & & Lixisenatide $20 \mu \mathrm{g}$ & 0.16 & -2086 & Dominant \\
\hline \multirow{4}{*}{$\begin{array}{l}\text { Treatment effects of HbAlc were } \\
\text { down-adjusted by a factor of } \\
7.28 \% / 8.2 \%\end{array}$} & \multirow[t]{4}{*}{ Exenatide $2 \mathrm{mg}$ vs. } & Dulaglutide $1.5 \mathrm{mg}$ & 0.05 & -1819 & Dominant \\
\hline & & Liraglutide $1.2 \mathrm{mg}$ & 0.09 & -1364 & Dominant \\
\hline & & Liraglutide $1.8 \mathrm{mg}$ & 0.04 & -3668 & Dominant \\
\hline & & Lixisenatide $20 \mu \mathrm{g}$ & 0.04 & -1459 & Dominant \\
\hline
\end{tabular}

The different profile of each drug could drive differences in outcomes for some specific subgroups, but the absence of robust evidence prevented performing this approach.

Despite the limitations described and the assumptions adopted, the results of univariate and probabilistic SAs confirmed the robustness of the base-case results.

\section{Conclusions}

This analysis suggests that exenatide $2 \mathrm{mg} /$ week is a dominant alternative (i.e. it is more effective and less costly) to dulaglutide $1.5 \mathrm{mg} /$ week, liraglutide $1.2 \mathrm{mg} /$ day, liraglutide $1.8 \mathrm{mg} / \mathrm{day}$, and lixisenatide $20 \mu \mathrm{g} /$ day to treat patients with T2DM that is inadequately controlled by metformin alone. 
Author Contributions IO and MM performed the economics analysis with the support of MC. AC and RMR provided clinical expert opinion on the disease area. The manuscript was drafted by IO and MM. All authors contributed to the interpretation and presentation of the findings, revised the article critically for important intellectual content, and approved the final version of the manuscript for submission.

Funding This study was funded by AstraZeneca Spain.

Data Availability Statement All data used in the analyses are available in this published article. The Microsoft Excel model described in this study is the proprietary of AstraZeneca, and access to the model is at the discretion of AstraZeneca.

\section{Compliance with ethical standards}

Conflicts of Interest María Mareque and Itziar Oyagüez are currently employed by PORIB, a consultant company specialising in economic evaluations of health interventions that received financial support from AstraZeneca for the development of this study. Andreea Ciudin and Raquel María Rodríguez-Rincón have received honoraria from PORIB for advocacy tasks related to this project. Margarita Capel and Susana Simón are employees of AstraZeneca Spain.

Open Access This article is distributed under the terms of the Creative Commons Attribution-NonCommercial 4.0 International License (http://creativecommons.org/licenses/by-nc/4.0/), which permits any noncommercial use, distribution, and reproduction in any medium, provided you give appropriate credit to the original author(s) and the source, provide a link to the Creative Commons license, and indicate if changes were made.

\section{References}

1. World Health Organization. World report on diabetes. World Health Organization; 2016 [cited 2018 May 21]. Available at: http://apps.who.int/iris/handle/10665/254649.

2. Ministry of Health, Social Services, and Equality. Strategy in Diabetes of the National Health System. Update. Ministry of Health, Social Services, and Equality; 2012.

3. Valdés S, Rojo-Martínez G, Soriguer F. Evolution of the prevalence of type 2 diabetes in the Spanish adult population. Med Clin (Barc). 2007;129(9):352-5.

4. Rojo G, Goday A, Boch E, Bordií E, Calle A, Carmena R, et al. Prevalence of diabetes and other abnormalities of carbohydrate metabolism in Spain. Estudio Di@bet.es Av Diabetol. 2011;27(Suppl 1):75-6.

5. Sicras-Mainar A, Navarro-Artieda R, Ibáñez-Nolla J. Clinical and economic characteristics associated with type 2 diabetes. Rev Clin Esp. 2014;214:121-30.

6. Zorrilla B, De la Calle H, Martínez M, Gil E, Sánchez JL, Nogales $\mathrm{P}$, et al. Prevalence study of Diabetes Mellitus in the Community of Madrid: PREDIMERC Study. Av Diabetol. 2008;24(Suppl 1):61.

7. Ryden L, Standl M, Bartnik M, van der Berghe G, Betteridge $\mathrm{J}$, de Boer M, et al. Guidelines on diabetes, pre-diabetes, and cardiovascular diseases: executive summary. The Task Force on Diabetes and Cardiovascular Diseases of the European Society of Cardiology (ESC) and of the European Association for the Study of Diabetes (EASD). Eur Heart J. 2007;28:88-136.

8. Ryden L, Standl M, Bartnik M, van der Berghe G, Betteridge $\mathrm{J}$, de Boer M, et al. Guidelines on diabetes, pre-diabetes, and cardiovascular diseases: executive summary. The Task Force on Diabetes and Cardiovascular Diseases of the European Society of Cardiology (ESC) and of the European Association for the Study of Diabetes (EASD). Eur Heart J. 2007;28:88-136.

9. Ruiz-Ramos M, Escolar-Pujolar A, Mayoral-Sánchez E, CorralSan Laureno F, Fernández-Fernández I. Diabetes mellitus in Spain: death rates, prevalence, impact, costs, and inequalities [in Spanish]. Gac Sanit. 2006;20(Suppl 1):15-24.

10. Global Burden of Disease Study 2013 Collaborators. Global, regional, and national incidence, prevalence, and years lived with disability for 301 acute and chronic diseases and injuries in 188 countries, 1990-2013: a systematic analysis for the Global Burden of Disease Study 2013. Lancet. 2015;386(9995):743-800.

11. Sociedad Española de Endocrinología y Nutrición (SEEN). http:// www.seen.es.

12. Fundación Red de Grupos de Estudio de Diabetes en Atención Primaria de la salud (redGDPS). Guía de actualización en diabetes mellitus tipo 2. 2016 [cited 2018 May 22]. Available at: http:// www.redgdps.org/guia-de-actualizacion-en-diabetes-20161005/.

13. Tran KL, Park YI, Pandya S, Muliyil NJ, Jensen BD, Huynh K, et al. Overview of glucagon-like peptide-1 receptor agonists for the treatment of patients with type 2 diabetes. Am Health Drug Benefits. 2017;10(4):178-88.

14. Aylwin C. New drugs in diabetes mellitus. Rev Med Clin Condes. 2016;27(2):235-56.

15. Eng C, Kramer CK, Zinman B, Betnakaran R. Glucagon-like peptide-1 receptor agonist and basal insulin combination treatment for the management of type 2 diabetes: a systematic review and meta-analysis. Lancet. 2014;384(9961):2228-34.

16. McEwan P, Evans M, Bergenheim K. A population model evaluating the costs and benefits associated with different oral treatment strategies in people with type 2 diabetes. Diabetes Obes Metab. 2010;12(7):623-30.

17. Clarke P, Gray A, Holman R. Estimating utility values for health states of type 2 diabetic patients using the EQ-5D (UKPDS 62). Med Decis Making. 2002;22(4):340-9.

18. López-Bastida J, Oliva J, Antoñanzas F, García-Altés A, Gisbert $\mathrm{R}$, Mar J, et al. Spanish recommendations on economic evaluation of health technologies. Eur J Health Econ. 2010;11(5):513-20.

19. National Institute for Health and Care Excellence. Appendix F: Full Health Economics Report. Type 2 diabetes in adults: management. Draft for consultation. 2015 [cited 2018 May 21]. Available at: http://www.nice.org.uk/guidance/gridcgwave0612/documents/ type-2-diabetes-appendix-f2.

20. Kayaniyil S, Lozano-Ortega G, Bennett HA, Johnsson K, Shaunik A, Grandy S, et al. A network meta-analysis comparing exenatide once weekly with other GLP-1 receptor agonists for the treatment of type 2 diabetes mellitus. Diabetes Ther. 2016;7(1):27-43.

21. National Institute of Statistics (Instituto Nacional de Estadística; INE). 2018 Mortality tables of Spanish population. National results. INEbase. Madrid: Instituto Nacional de Estadística [cited 2017 September 11]. Available at: http://www.ine.es.

22. Depablos-Velasco P, Salguero-Chaves E, Mata-Poyo J, Derivas-Otero B, García-Sánchez R, Viguera-Ester P. Quality of life and treatment satisfaction in subjects with type 2 diabetes: results of the PANORAMA study in Spain. Endocrinol Nutr. 2014;61(1):18-26.

23. Clarke PM, Gray AM, Briggs A, Farmer AJ, Fenn P, Stevens RJ, et al. A model to estimate the lifetime health outcomes of patients with type 2 diabetes: the United Kingdom Prospective Diabetes Study (UKPDS) Outcomes Model (UKPDS no 6.8). Diabetologia. 2004;47(10):1747-59.

24. Bagus A, Beale S. Modelling EuroQol health-related utility values for diabetic complications from CODE-2 data. Health Econ. 2005;14(3):217-30. 
25. Currie CJ, Morgan CL, Poole CD, Sharplin P, Lammert M, McEwan P. Multivariate models of health-related utility and the fear of hypoglycaemia in people with diabetes. Curr Med Res Opin. 2006;22(8):1523-34.

26. Lane S, Levy AR, Mukherjee J, Sambrook J, Tildesley H. The impact on utilities of differences in body weight among Canadian patients with type 2 diabetes. Curr Med Res Opin. 2014;30(7):1267-73.

27. National Institute of Statistics (Instituto Nacional de Estadísitica; INE). http://www.ine.es.

28. General Council of Official Associations of Pharmacists. Health Knowledge Database-Bot Plus 2.0. Madrid: General Council of Official Associations of Pharmacists; 2017 [cited 2018 May 8]. Available at: https://botplusweb.portalfarma.com/.

29. Ministry of Health, Social Services, and Equality. Listing of medicines affected by the deductions established in Royal Decree-Law 8/2010 of May 20, by which extraordinary measures are adopted to reduce the public deficit. May 2018 [cited 2018 May 10]. Available at: https://www.msssi.gob.es/profesionales/farmacia/pdf/ DeduccionesMayo2018.pdf.

30. Order SSI/1157/2017, of November 28, which updates in 2017 the reference price system of medicines in the National Health System. Madrid: Agencia Estatal Boletín Oficial del Estado; 2017 [cited 2018 May 9]. Available at: https://www.boe.es/diario_boe/ txt.php?id=BOE-A-2017-13834.

31. World Health Organization. ATC/DDD index. WHO collaborating centre of drug statistics methodology. World Health Organization; 2013 [cited 2018 May 10]. Available at: https://www.whocc.no/ atc_ddd_index/.

32. Ministry of Health, Social Services, and Equality. Exploitation of the Minimum Basic Data Set. 2013 [cited 2018 May 10]. Available at: http://pestadistico.inteligenciadegestion.msssi.es/.

33. López-Bastida J, Oliva Moreno J, Worbes Cerezo M, Perestelo Pérez L, Serrano-Aguilar P, Montón-Álvarez F. Social and economic costs and health-related quality of life in stroke survivors in the Canary Islands, Spain. BMC Health Serv Res. 2012;12:315.

34. Schwarz B, Gouveia M, Chen J, Nocea G, Jameson K, Cook J, et al. Cost-effectiveness of sitagliptin-based treatment regimens in European patients with type 2 diabetes and haemoglobin A1c above target on metformin monotherapy. Diabetes Obes Metab. 2008;10(Suppl 1):43-55.

35. Oblikue Consulting. Database of health costs, eHealth. Barcelona: Oblikue Consulting; 2017 [cited 2018 May 8]. Available at: http:// www.oblikue.com/bddcostes/.

36. Counterweight Project Team. Influence of body mass index on prescribing costs and potential cost savings of a weight management programme in primary care. J Health Serv Res Policy. 2008;13(3):158-66.

37. Hammer M, Lammert M, Mejías SM, Kern W, Frier BM. Costs of managing severe hypoglycaemia in three European countries. J Med Econ. 2009;12(4):281-90.

38. Mata M, Antonanzas F, Tafalla M, Sanz P. The cost of type 2 diabetes in Spain: the CODE-2 study [in Spanish]. Gac Sanit. 2002;16(6):511-20.

39. Menéndez Torre E, Lafita Tejedor J, Artola Menéndez S, Milán Núñez-Cortés J, Alonso García A, Puig Domingo M, et al. Recommendations for the pharmacologic treatment of hyperglycemia in type 2 diabetes. Consensus document. Nefrologia. 2011;31(1):17-26.

40. Willis M, Asseburg C, Nilsson A, Johnsson K, Kartman B. Multivariate prediction equations for $\mathrm{HbA}$ (1c) lowering, weight change, and hypogycemic events associated with insulin rescue medication in type 2 diabetes mellitus: informing economic modeling. Value Health. 2017;20(3):357-71.
41. Vallejo-Torres L, García-Lorenzo B, Rivero-Arias O, Pinto-Prades JL, Serrano-Aguilar P. Disposición a pagar de la sociedad española por un Año de Vida Ajustado por Calidad. Ministerio de Sanidad, Servicios Sociales e Igualdad. Servicio de Evaluación del Servicio Canario de la Salud; 2016. Informes de Evaluación de Tecnologías Sanitarias.

42. Crespo C, Brosa M, Soria-Juan A, López-Alba A, López-Martínez $\mathrm{N}$, Soria B. Direct costs of diabetes mellitus and its complications in Spain. SECCAID study. Av Diabetol. 2013;29:182-9.

43. Ministry of Health, Social Services, and Equality. Spanish Agency of Medicines and Health Products. Therapeutic positioning report of dulaglutide (Trulicity ${ }^{\circledR}$ ); 2016 [cited 2018 June 12]. Available at: https://www.aemps.gob.es/medicamentosUsoHumano/infor mesPublicos/docs/IPT-dulaglutida-trulicity.pdf.

44. Chuang LH, Verheggen BG, Charokopou M, Gibson D, Grandy S, Kartman B. Cost-effectiveness analysis of exenatide once-weekly versus dulaglutide, liraglutide, and lixisenatide for the treatment of type 2 diabetes mellitus: an analysis from the UK NHS perspective. J Med Econ. 2016;19(12):1127-34.

45. Basson M, Ntais D, Ayyub R, Wright D, Lowin J, Chartier F, et al. The cost-effectiveness of dulaglutide $1.5 \mathrm{mg}$ versus exenatide QW for the treatment of patients with type 2 diabetes mellitus in France. Diabetes Ther. 2018;9(1):13-25.

46. Hunt B, Kragh N, McConnachie CC, Valentine WJ, Rossi MC, Montagnoli R. Long-term cost-effectiveness of two GLP-1 receptor agonists for the liraglutide versus lixisenatide. Clin Ther. 2017;39(7):1347-59.

47. Hunt B, Ye Q, Valentine WJ, Ashley D. Evaluating the long-term cost-effectiveness of daily administered GLP-1 receptor agonists for the treatment of type 2 diabetes in the United Kingdom. Diabetes Ther. 2017;8(1):129-47.

48. Mezquita-Raya P, Ramírez de Arellano A, Kragh N, Vega-Hernandez G, Pöhlmann J, Valentine WJ, et al. Liraglutide versus lixisenatide: long-term cost-effectiveness of GLP-1 receptor agonist therapy for the treatment of type 2 Diabetes in Spain. Diabetes Ther. 2017;8(2):401-15.

49. Song F, Altman DG, Glenny AM, Deeks JJ. Validity of indirect comparison for estimating efficacy of competing interventions: empirical evidence from published meta-analyses. BMJ. 2003;326(7387):472.

50. Greiner W, Weijnen T, Nieuwenhuizen M, Oppe S, Badia X, Busschbach J, et al. A single European currency for EQ-5D health states. Results from a six-country study. Eur J Health Econ. 2003;4(3):222-31.

51. National Institute of Statistics (Instituto Nacional de Estadística; INE). Household panel of the European Union. Mean height of the population by countries, sex, period, and age. www.ine.es.

52. National Institute of Statistics (Instituto Nacional de Estadística; INE). Household panel of the European Union. Mean weight of the population by countries, sex, period, and age. www.ine.es.

53. Alvarez Guisasola F, Tofé Povedano S, Krishnarajah G, Lyu R, Mavros P, Yin D. Hypoglycaemic symptoms, treatment satisfaction, adherence and their associations with glycaemic goal in patients with type 2 diabetes mellitus: findings from the RealLife Effectiveness and Care Patterns of Diabetes Management (RECAP-DM) Study. Diabetes Obes Metab. 2008;10(Suppl 1):25-32.

54. Gil Montalbán E, Zorrilla Torras B, Ortiz Marrón H, Martínez Cortés M, Donoso Navarro E, Nogales Aguado P, et al. Prevalence of diabetes mellitus and cardiovascular risk factors in the adult population of the Community of Madrid: PREDIMERC study [in Spanish]. Gac Sanit. 2010;24(3):233-40. 